\title{
PROTECTIVE EFFECT OF BLEPHAROSPASM ON THE ANTERIOR SEGMENT OF THE EYE
}

\author{
Dubravka Biuk ${ }^{1}$, Maja Vinković ${ }^{1}$, Josip Barać ${ }^{1}$, Egon Biuk ${ }^{2}$, Zoran Zelić ${ }^{2}$ and Suzana Matić \\ ${ }^{1}$ Department of Ophthalmology, Osijek University Hospital Centre, Faculty of Medicine, \\ Josip Juraj Strossmayer University of Osijek, Osijek, Croatia; \\ ${ }^{2}$ Department of Orthopedic Surgery, Osijek University Hospital Centre, Faculty of Medicine, \\ Josip Juraj Strossmayer University of Osijek, Osijek, Croatia
}

\begin{abstract}
SUMMARY - The aim of the study was to determine the role of blepharospasm as a protective factor for the anterior segment of the eye by comparing the degree of blepharospasm and changes of the anterior segment structures. The study included sixty female patients older than forty years with the clinical diagnosis of blepharospasm. They were divided into two groups; the first group consisted of patients with stage I and II of blepharospasm with dominant dry eye symptoms, and the second group consisted of patients with stage III and IV of blepharospasm who required interventional therapy (all patients in this study were treated with botulinum toxin type A). Staining of ocular surface with vital dyes such as fluorescein was used to determine ocular surface defects. Fluorescein stains the corneal epithelial defects, which were statistically less pronounced in the interventional group. In conclusion, comparison of the results between the two groups of patients may implicate that advanced blepharospasm has a protective effect on ocular surface.
\end{abstract}

Key words: Blepharospasm; Dry eye syndrome; Staining and labeling; Protective factors; Fluorescein

\section{Introduction}

Blepharospasm is a periodic involuntary contraction of the orbicular muscle and can be part of clinical findings of dystonia or exist as a separate ophthalmological entity ${ }^{1-3}$. It is often unrecognized and confused with dry eye syndrome $e^{4,5}$. The leading symptom is functional blindness because visual acuity is reduced due to frequent blinking. Blepharospasm patients complain of grittiness in the eye, eye dryness, or photophobia. Clinical examination of the anterior segment is usually normal or reveals signs of chronic conjunctivitis, keratitis and/or iritis.

The prevalence of blepharospasm is 3-13/100,000, it is more common in women (female to male ratio,

Correspondence to: Dubravka Biuk, MD, Department of Ophthalmology, Osijek University Hospital Centre, Europska avenija 14-16, HR-31000 Osijek, Croatia

E-mail:dubravka.biuk@gmail.com

Received December 20, 2016, accepted August 22, 2017
3:1) and occurs predominantly in older age groups (55-65 years).

Primary blepharospasm usually begins with high frequency twitching spontaneously or in response to stress stimuli, and can be intensified by bright light, irritation (smoking, wind), emotional stress, looking up/down, walking, reading or watching TV. Blepharospasm can be classified into four stages: mild - response to external stimuli; moderate - does not affect vision but can be distressing; expressed - interferes with communication; and pronounced - disables reading and walking.

In the early stages of the disease (stages I and II), the dry eye symptoms predominate ${ }^{2,3,6}$; as the condition progresses (stages III and IV), these symptoms are less pronounced.

The aim of the study was to determine the effect of blepharospasm as a protective factor on the anterior segment of the eye by comparing the stage of the disease and ocular surface changes. 
Fluorescein staining is enhanced with cell degeneration or cell death, which increases membrane permeability to fluorescein. Fluorescein staining is increased by rapid stromal diffusion and therefore can manifest whenever there is disruption of cell-cell junctions ${ }^{7}$. Rapid stromal diffusion explains why fluorescein is best suited to measure corneal epithelial and endothelial permeability, as well as to evaluate epithelial toxicity caused by agents known to disrupt epithelial tight junctions ${ }^{8}$. Fluorescein rapid stromal diffusion interferes with differentiation of the stained cells from intercellular staining and makes it less ideal for conjunctival staining 9 .

\section{Patients and Methods}

The study involved 60 female patients older than 40 with the clinical diagnosis of blepharospasm, divided into two groups (each group consisting of thirty patients): group 1, patients with blepharospasm stage I and II with predominant symptoms of dry eye (control group); and group 2, patients with blepharospasm stages III and IV that required an interventional therapeutic approach (all patients in this study received botulinum toxin type A).

The patients with glaucoma or ocular hypertension prior to or acquired during the study period were excluded because they may have had ocular surface defects due to constant use of topical antiglaucoma medication. Patients having undergone surgical procedures of the anterior or posterior segment of the eye, as well as those in whom Botox was contraindicated were excluded from the study.

Clinical examination of the subjects enrolled in the research consisted of the following: examination of the periocular area for signs of infection or injuries, as well as to determine the stage of blepharospasm; assessment of visual acuity by Snellen optotypes; Goldmann applanation tonometry to exclude subjects with glaucoma or ocular hypertension; and slit lamp biomicroscopy (Haag-Streit, Berne, Switzerland). Staining of ocular surface with $1 \%$ fluorescein solution was followed by slit lamp biomicroscopy under cobalt blue light. Ocular surface defects stain with fluorescein. Staining is represented by punctate dots on a series of panels (Bron Evans Smith 2003). Staining range is 0-5 for each panel and 0-15 for the total exposed interpalpebral conjunctiva and cornea.
Descriptive statistical methods were used to describe the distribution of frequency of the variables tested. All variables were tested by KolmogorovSmirnov test for equality of probability distribution. The values of continuous variables were expressed by arithmetic mean and standard deviation (SD) for normally distributed variables, and by median and range for unequally distributed variables. Nominal indicators were expressed by frequency distribution according to groups and share. Mann-Whitney test was used to determine differences between two independent samples. To determine differences between proportions of the two independent samples, $\chi^{2}$-test was performed.

A level of significance of $\alpha=0.05$ was chosen for the results obtained.

\section{Results}

The study was conducted on the population of 60 female patients aged $>40$, allocated to two groups according to the degree of blepharospasm. The mean age was 66.3 years in control group subjects and 70.8 years in the interventional therapy group (Table 1 ).

Table 1. Basic measures and scatter of age in both patient groups

\begin{tabular}{|l|l|l|l|}
\hline \multirow{2}{*}{ Group } & \multicolumn{2}{|c|}{ Patient age } & \multirow{2}{*}{$\mathrm{p}^{*}$} \\
\cline { 2 - 4 } & Mean age (SD) & Min-Max & \\
\hline $\begin{array}{l}\text { Control group } \\
\begin{array}{l}\text { Interventional } \\
\text { therapy group }\end{array}\end{array}$ & $66.3(10.13)$ & $44-87$ & 0.102 \\
\hline Total & $68.6(10.23)$ & $51-87$ & \\
\hline
\end{tabular}

$\mathrm{SD}=$ standard deviation; 'Mann Whitney test

The need of interventional therapy for blepharospasm appeared to increase with age.

The mean value of fluorescein test was $8.4( \pm 1.88)$, ranging from 5 to 12 in the control group and 6.6 $( \pm 1.42)$, ranging from 5 to 10 in the group with stages III and IV of blepharospasm, yielding a statistically significant difference (Mann Whitney test, $\mathrm{p}<0.001$ ) (Fig. 1).

Fourteen (23.3\%) patients had score 6, including 12 (40\%) patients from the interventional therapy group and two (6.7\%) patients from the control group. 


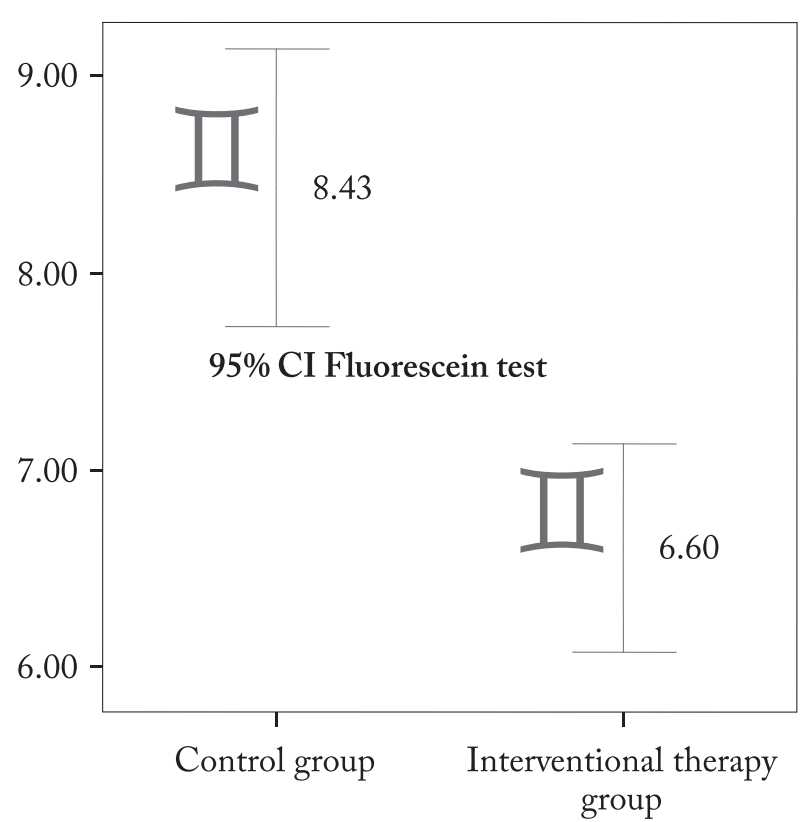

Fig. 1. Median and confidence interval of fluorescein test in two patient groups.

In the interventional therapy group, most of the subjects had score 6; an approximately equal number of patients, i.e. six (20\%) patients had score 5 and 7, and two (6.7\%) patients had score 8 to 10 .

In the control group, 3.3\%-23.3\% of subjects had a significantly higher fluorescein test score (8 to 12 ), as opposed to the interventional therapy group where none of the patients had fluorescein test score $>10$ $\left(\chi^{2}\right.$-test, $\left.\mathrm{p}=0.009\right)$ (Table 2).

Table 2. Distribution of fluorescein test results between the groups

\begin{tabular}{|l|l|l|l|l|}
\hline \multirow{2}{*}{$\begin{array}{l}\text { Fluorescein } \\
\text { test }\end{array}$} & $\begin{array}{l}\text { Control } \\
\text { group }\end{array}$ & $\begin{array}{l}\text { Interventional } \\
\text { therapy group }\end{array}$ & Total & \multirow{2}{*}{ * $^{*}$} \\
\cline { 2 - 4 } & $\mathrm{n}(\%)$ & $\mathrm{n}(\%)$ & $\mathrm{N}(\%)$ & \\
\hline 5 & $2(6.7)$ & $6(20)$ & $8(13.3)$ & \\
6 & $2(6.7)$ & $12(40)$ & $14(23.3)$ & \\
7 & $6(20)$ & $6(20)$ & $12(20)$ & \\
8 & $7(23.3)$ & $2(6.7)$ & $9(15)$ & 0 \\
9 & $4(13.3)$ & $2(6.7)$ & $6(10)$ & 0.009 \\
10 & $3(10)$ & $2(6.7)$ & $5(8.3)$ & \\
11 & $5(16.7)$ & 0 & $5(8.3)$ & \\
12 & $1(3.3)$ & 0 & $1(1.7)$ & \\
\hline Total & $30(100)$ & $30(100)$ & $60(100)$ & \\
\hline
\end{tabular}

${ }^{*} \chi^{2}$-test

\section{Discussion}

The mean age of patients was 66.3 years in group 1 and 70.8 years in group 2. In the interventional therapy group, $36.7 \%$ of patients were older than 75 , while the majority (50\%) of control group subjects were aged 66 to 75. Age distribution indicated the need for interventional therapy to increase with age, in concordance with progression of the clinical signs of blepharospasm.

The study included only female patients since there is a higher female prevalence of blepharospasm (female to male ratio, 3:1). Various epidemiological studies have reported that dry eye syndrome, present in almost all patients with blepharospasm, also has a higher prevalence in females, especially postmenopausal $^{10}$ and elderly women ${ }^{11-14}$. By inclusion of only female patients in the study, we tried to bypass the possible discrepancies in the interpretation of results, which may have been altered by hormonal influence on the expression of dry eye symptoms.

Staining with $1 \%$ fluorescein solution, which stains corneal epithelial defects and mucous fibrils, is used in the diagnosis of dry eye $\mathrm{e}^{15-17}$. Fluorescein penetrates the disrupted cell-cell junctions. The pathognomonic corneal epithelial defect staining profile of dry eye is bilateral, symmetric, punctiform and diffuse corneal staining, involving the 6-o'clock position on the cornea and interpalpebral area of the bulbar conjunctiva. By comparing the fluorescein test staining between the two groups of patients, only conjunctiva stained with fluorescein, mostly pronounced in the interpalpebral rim, was recorded in the interventional therapy group, whereas corneal surface stained with fluorescein, especially the lower part of the cornea, was also recorded in the control group. Another important observation derived from these data was that the fluorescein test score was significantly lower in the interventional therapy group, where it did not exceed the value of 10 . Since fluorescein stains epithelial defects, it seems logical to assume that the level of clinical expression of blepharospasm may have a protective role on ocular surface.

It is important to emphasize that positive fluorescein staining of the cornea does not necessarily mean pathological finding. The otherwise normal corneas have positive fluorescein staining in at least $16 \%$ of cases $^{18-20}$. The percentage of fluorescein positive asymptomatic corneas increases with age, from approximately $4 \%$ positive staining in subjects younger than 40 to $20 \%$ in those older than $50^{19}$. 


\section{Conclusion}

Advanced blepharospasm has a protective role on the ocular surface, which is confirmed by fluorescein tests. Fluorescein stains epithelial defects, which were statistically significantly less pronounced in the interventional therapy group.

\section{References}

1. Marsden CD, Fahn S. Dystomia 3. Summary and conclusions. Adv Neurol. 1998;78:359-64.

2. Jankovic J, Ford J. Blepharospasm and orofacial-cervical dystonia: clinical and pharmacological findings in 100 patients. Ann Neurol. 1983 Apr;13(4):402-11.

3. Grandes F, Elston J, Quinn N, Marsden CD. Blepharospasm: a review of 264 patients. J Neurol Neurosurg Psychiatry. 1988 Jun;51(6):767-72.

4. Logroscino G, Livrea P, Anaclerio D, Aniello MS, Benedetto G, Cazzato G, et al. Agreement among neurologists on the clinical diagnosis of dystonia at different body sites. J Neurol Neurosurg Psychiatry. 2003 Mar;74(3):348-50. doi: 10.1136/jnnp.74.3.348

5. Tseng SC, Tsubota K. Important concepts for treating ocular surface and tear disorders. Am J Ophthalmol. 1997 Dec;124 (6):825-35.

6. Elston JS, Marsden CD, Grandas F, Quinn NP. The significance of ophthalmological symptoms in idiopathic blepharospasm. Eye (Lond). 1988;2(Pt 4):435-9.

7. Feenstra RP, Tseng SC. Comparison of fluorescein and rose bengal staining. Ophthalmology. 1992 Apr;99(4):605-17.

8. Kim J, Foulks GN. Evaluation of the effect of lissamine green and rose bengal on human corneal epithelial cells. Cornea. 1999 May;18(3):328-32.
9. Manning FJ, Wehrle SR, Foulks GN. Patient tolerance and ocular surface staining characteristics of lissamine green versus rose bengal. Ophthalmology. 1995 Dec;102(12):1953-7.

10. Murube J, Rivas L. Impression cytology on conjunctiva and cornea in dry eye patients establishes a correlation between squamous metaplasia and dry eye clinical severity. Eur J Ophthalmol. 2003 Mar;13(2):115-27.

11. Yazdani C, McLaughlin T, Smeeding JE, Walt J. Prevalence of treated dry eye disease in a managed care population. Clin Ther. 2001 Oct;23(10):1672-82.

12. Moss SE, Klein R, Klein BE. Prevalence of and risk factors for dry eye syndrome. Arch Ophthalmol. 2000 Sep;118(9):1264-8.

13. Lin PY, Tsai SY, Cheng CY, Liu JH, Chou P, Hsu WM. Prevalence of dry eye among an elderly Chinese population in Taiwan: the Shihpai Eye Study. Ophthalmology. 2003 Jun;110(6):1096-101. https://doi.org/10.1016/S0161-6420(03)00262-8

14. Schaumburg DA, Sullivan DA, Dana MR. Epidemiology of dry eye syndrome. Adv Exp Med Biol. 2002;506(Pt B):989-98.

15. Kim J. The use of vital dyes in corneal disease. Curr Opin Ophthalmol. 2000 Aug;11(4):241-7.

16. Bron AJ, Evans VE, Smith JA. Grading of corneal and conjunctival staining in the context of other dry eye tests. Cornea. 2003 Oct;22(7):640-50.

17. Nichols KK, Mitchell GL, Zadnik K. The repeatability of clinical measurements of dry eye. Cornea. 2004 Apr;23(3):272-85. https://doi.org/10.1016/j.jtos.2017.09.006

18. Korb DR, Korb JM. Corneal staining prior to contact lens wearing. J Am Optom Assoc. 1970 Mar;41(3):228-32.

19. Norn MS. Micropunctate fluorescein vital staining of the cornea. Acta Ophthalmol (Copenh). 1970;48(1):108-18.

20. Korb DR, Herman JP. Corneal staining subsequent to sequential fluorescein instillations. J Am Optom Assoc. 1979 Mar; 50(3):361-7.

\section{ZAŠTITNI UČINAK BLEFAROSPAZMA NA PREDNJI OČNI SEGMENT}

\section{Biuk, M. Vinković, J. Barać, E. Biuk, Z. Zelić i S. Matić}

Cilj rada bio je odrediti ulogu blefarospazma kao zaštitnog čimbenika prednjeg segmenta oka usporedbom stupnja blefarospazma i promjenama prednjeg segmenta oka. Rad je uključivao 60 žena starijih od 40 godina s kliničkom slikom blefarospazma podijeljenih u dvije skupine. Prvu skupinu činile su bolesnice s I. i II. stupnjem blefarospazma kod kojih su dominirali simptomi suhog oka, a drugu skupinu činile su bolesnice III. i IV. stupnja blefarospazma kod kojih je bila potrebna interventna terapija (sve bolesnice su bile liječene botulin toksinom tipa A). Za bojanje okularne površine radi otkrivanja kornealnih epitelnih defekata rabio se fluorescein. Bojanje kornealnih epitelnih defekata fluoresceinom bilo je statistički značajno manje u intervencijskoj skupini. Usporedba rezultata između promatranih skupina ukazala je na to da izraženi blefarospazam ima zaštitnu ulogu na površinu oka.

Ključne riječi: Blefarospazam; Suho oko, sindrom; Bojenje i označavanje preparata; Zaštitni faktori; Fluorescein 